\title{
PSIKOLOGI DAN PEMBELAJARAN MATEMATIKA
}

\author{
Nurdiana Siregar \\ 'PGSD, Universitas Nahdlatul Ulama Sumatera Utara \\ Email :nurdiana884@yahoo.co.id
}

\begin{abstract}
ABSTRAK
Pemahaman guru terhadap psikologis anak perlu diterapkan dalam pembelajaran matematika. Pemahaman guru tersebut antara lain: kemampuan anak dalam memahami matematika, perkembangan mental (usia) dan pengalaman anak, emosi anak, keyakinan dan skema diri, minat dan motivasi anak ketika dalam pembelajaran matematika. Kemampuan (pemroresan informasi) anak dalam memahami matematika didasarkan pada teori perkembangan mental Piaget, Bruner, Dienes, dan Van Hiele. Teori belajar tersebut merupakan dasar bagi guru matematika dalam menciptakan pembelajaran matematika yang efektif dan efisien.
\end{abstract}

Kata kunci: psikologi, pembelajaran matematika

\begin{abstract}
Understanding of teachers on child psychology needs to be applied in learning mathematics. Understanding of teachers include: the ability of children in understanding mathematics, mental development (age) and children's experiences, child emotions, beliefs and self-schemes, interests and motivation of children when in learning mathematics. The child's ability to understand mathematics is based on the mental development theories of Piaget, Bruner, Dienes, and Van Hiele. The learning theory is the basis for mathematics teachers in creating effective and efficient mathematics learning.
\end{abstract}

Keywords: psychology, learning mathematic

\section{PENDAHULUAN}

Dalam mencapai tujuan pembelajaran matematika, banyak faktor yang menentukannya. Salah satunya, jika materi matematika diajarkan sesuai dengan tingkat berpikir anak dan keadaan psikologis siswa. Oleh karena itu, seorang guru matematika tidak hanya diharuskan untuk menguasai materi 
matematika, tetapi juga memahami keadaan psikologis siswa. Jadi memasukkan materi matematika pada siswa akan mudah bagi guru.

Guru SD, SMP, dan SMA perlu memahami psikologis siswa dalam belajar matematika, mengingat anak di usia SD, SMP, dan SMA yang masih labil. Di usia anak sedini mungkin yaitu usia SD, guru mesti bisa membuat siswa tertarik mempelajari matematika dan berlanjut hingga ke jenjang SMA. Pada umumnya, siswa akan belajar bila Dia menyukai pelajaran tersebut dan siswa menyukai pelajaran itu dikarenakan gurunya. Dengan kata lain, sukanya seseorang belajar matematika itu tergantung gurunya. Jika ia menyukai gurunya maka ia akan belajar dan sebaliknya bila ia tidak menyukai gurunya maka ia tidak akan belajar. Dapat dikatakan salah satu tugas guru yaitu membuat siswa menghargai kegunaan matematika seperti memiliki rasa ingin tahu, minat dan percaya diri dalam pemecahan masalah matematika.

Setiap pembelajaran objek sasarannya adalah siswa, begitu juga halnya dengan pembelajaran matematika. Namun dalam mencapai indikator pembelajaran pada materi pokok matematika terhadap sejumlah siswa dalam kelas dan tekanan waktu membuat guru sering menggunakan metode ceramah. Penggunaan metode ceramah secara terus menerus dalam pembelajaran matematika, dapat dikatakan pengabaian aspek psikologis siswa. Siswa secara terus menerus disuguhi berbagai aksioma, definisi, teorema, dan rumus matematika secara langsung, tanpa memberikan siswa mendapatkan pengalaman untuk menemukannya.

Siswa dengan aspek pikologisnya tidak lepas dari kajian pembelajaran matematika. Karakteristik matematika yang objeknya abstrak dan berjenjang menyebabkan siswa mengalami kesulitan dalam mempelajarinya. Oleh karena itu, pemahaman psikologis siswa ketika mempelajari matematika sangat penting untuk dikaji. Aspek psikologis siswa diantaranya adalah kemampuan berpikirnya, emosi, minat, keyakinan dan skema diri, dan motivasi siswa dalam pembelajaran matematika. 


\section{PEMRORESAN INFORMASI}

Siswa dalam kelas memiliki kecepatan belajar yang berbeda antara yang satu dengan yang lainnya. Kecepatan belajar bisa disebut inteligensi. Banyak ahli yang menyatakan bahwa inteligensi atau kecerdasan itu sudah bawaan sifat gen dari orang tua dan suatu yang tidak bisa dirubah. Di lain pihak, kecerdasan itu bisa ditingkatkan dengan sering mengasahnya.

Kemampuan anak dalam memahami suatu hal berkaitan dengan usia (perkembangan mental) anak. Ruseffendi (1991:132) menyatakan ada beberapa teori perkembangan mental yang dianjurkan utuk dipergunakan dalam pembelajaran matematika, diantaranya:

\section{Teori Piaget}

Suatu respon dapat dipahami dikarenakan bekerjanya skemata. Skemata adalah struktur kognitif berupa ide, konsep, prinsip, dan gagasan. Skema berkembang secara terus menerus yang dipengaruhi oleh tiga proses yaitu asimilasi, akomodasi, dan ekuilibrasi. Asimilasi adalah proses pengintegrasian konsep atau pengalaman baru kedalam struktur kognitif yang telah ada dalam pikiran. Akomodasi adalah proses penyesuaian struktur kognitif terhadap situasi baru sehingga struktur mental baru terbentuk atau termodivikasi. Ekuilibrasi adalah proses yang terjadi pada seseorang untuk mempertahankan proses-proses pikiran yang seimbang yang melibatkan asimilasi dan akomodasi.

Piaget percaya bahwa setiap individu melewati empat tahap perkembangan kognitif secara berurutan yaitu tahap sensorimotor (0-2 tahun), tahap Pra-operasional (2-7 tahun), tahap operasional-konkret (7-11 tahun), dan tahap operasional formal (11-dewasa). Anak pada tahap praoperasional mulai dapat membilang dengan menggunakan benda-benda konkret dan dapat mengelompokkan benda-benda berdasarkan satu sifat khusus yang sederhana. Tahap operasional-konkret adalah tahap perkembangan anak Sekolah Dasar (SD), yang umumnya memahami operasi logis dengan bantuan benda-benda konkret, memahami konsep kekekalan 
(kekekalan banyak pada usia 6-7 tahun, kekekalan materi pada usia 7-8 tahun, kekekalan panjang pada usia 7-8 tahun, kekekalan luas pada usia 8-9 tahun, kekekalan berat pada usia 9-10 tahun, dan kekekalan volume pada usia 11-12 tahun), kemampuan mengaklasifikasi benda-benda dan mengurutkan objek, mampu melihat sudut pandang orang lain, dapat menyelesaikan soal-soal seperti $+3=9$, dapat menggunakan tambang panjang 3, 4, dan 5m dan bilangan pytagoras lainnya untuk membuat segitiga siku-siku, dapat memanipulasi benda, dan dapat memberikan alasan deduktif dan induktif. Anak pada tahap operasi formal sudah mampu melakukan penalaran dengan menggunakan hal-hal yang abstrak, dapat merumuskan dalil/ teori (misalnya dalil pythagoras), dapat memandang definisi, aturan, dan dalil dalam konteks yang benar dan objektif, dapat berpikir deduktif dan induktif, anak dewasa mampu mengerti konteks kompleks seperti permutasi, kombinasi, perbandingan, korelasi dan probabilitas, dan dapat mengerti besar tak hingga dan kecil tak hingga.

\section{Teori Jerome S.Bruner}

Anak dalam proses belajarnya melalui 3 tahap yaitu enaktif, ikonik, dan simbolik. Tahap enaktif, anak secara langsung terlibat dalam memanipulasi (mengotak-atik) objek. Tahap ikonik, kegiatan yang dilakukan merupakan gambaran dari objek-objek yang dimanipulasinya. Tahap simbolik, anak sudah mampu menggunakan notasi tanpa tergantung lagi terhadap objek nyata.

Hasil pengamatan Bruner ke sekolah-sekolah dan hasil percobaan teman-temannya, Bruner melahirkan dalil-dalil, yaitu dalil penyusunan, dalil notasi, dalil kekontrasan dan dalil keanekaragaman, dan dalil pengaitan. Dalil-dalil tersebut dikaitkan dengan pembelajaran matematika.

Dalil penyusunan, suatu konsep akan lebih melekat bila kegiatankegiatan yang menunjukkan representasi konsep itu dilakukan oleh siswa sendiri. Misalnya untuk memahamkan konsep penjumlahan, yaitu $2+3$, 
siswa sendiri yang melakukan 2 langkah berurutan yaitu 2 kotak dan 3 kotak pada peta garis bilangan.

Dalil notasi, penggunaan notasi di sesuaikan dengan perkembangan mental siswa. Notasi \{\} tidak diberikan kepada siswa dipermulaan SD. Notasi fungsi $\mathrm{f}(\mathrm{x})$ hanya dipakai untuk siswa SMA atau di perguruan tinggi, sedangkan untuk siswa $\mathrm{SD}$ tanda $\square$ atau $\triangle$, misalnya $9=\Delta+4$.

Dalil pengkontrasan dan keanekaragaman yaitu konsep harus dikontraskan dengan konsep-konsep lainnya dan disajikan dengan beranekaragam contoh. Misalnya bilangan ganjil dikontraskan dengan bilangan genap, ruas garis dikontraskan dengan garis dan sinar. Konsep perkalian menggunakan himpunan, garis bilangan, jajaran, pemasangan, daerah bujur sangkar.

Dalil pengaitan, siswa harus lebih banyak diberi kesempatan untuk melihat kaitan-kaitan matematika misalnya antar dalil, antar teori, antar topik, antar cabang matematika misalnya aljabar dan geometri. Hal tersebut dilakukan mengingat karakteristik matematika itu sendiri, yaitu antara konsep matematika terdapat hubungan yang erat.

\section{Teori Zoltan P.Dienes}

Konsep adalah struktur matematika yang terdiri dari konsep murni matematika, konsep notasi, dan konsep terapan. Siswa bisa memahami konsep matematika apabila diajarkan secara terurut yaitu dimulai dari konsep murni, dilanjutkan konsep notasi, dan diakhiri konsep terapan dan konsep matematika tersebut direpresentasi dimulai dengan benda-benda konkret yang beraneka ragam.

Ada enam tahap dalam membelajarkan konsep matematika yaitu (1) bermain bebas, (2) permainan, (3) penelaahan sifat bersama, (4) representasi, (5) penyimbolan, (6) pemformalan. Bermain bebas yaitu anak belajar bebas, tidak diatur, tidak diarahkan dan bermain-main dengan bendabenda konkret model matematika. Pada tahap permainan, anak mulai mengamati pola, sifat-sifat kesamaan/ ketidaksamaan, keteraturan/ 
ketidakteraturan suatu konsep yang diwakili (disajikan) oleh benda-benda yang konkret. Pada tahap ketiga, siswa belajar hingga dapat menghayatinya dan dapat menunjukkan contoh dan bukan contoh. Pada tahap representasi, siswa membuat pernyataan tentang konsep berupa diagram atau lisan. Pada tahap penyimbolan, siswa diberi kesempatan mencari simbol sendiri, namun demi keseragaman, akhirnya guru menentukan simbolnya sesuai yang berlaku dalam matematika. Tahap pemformalan, siswa belajar mengorganisasikan konsep-konsep matematika secara formal sehingga sampai kepada aksioma, dalil atau teori.

\section{Teori Van Hiele}

Ada lima tahap (perkembangan mental) anak dalam memahami geometri yaitu pengenalan, analisis, pengurutan, deduksi, dan keakuratan. Tahap pengenalan yaitu siswa mengenal bentuk-bentuk geometri seperti segitiga, kubus, bola, lingkaran, dan sebagainya. Tahap analisis yaitu siswa memahami sifa-sifat dari bentuk geometri. Tahap pengurutan, siswa sudah paham hubungan antar bentuk geometri. Tahap deduksi, berpikir deduktif siswa sudah mulai tumbuh, siswa sudah memahami pentingnya mengambil kesimpulan secara deduktif, memahami pentingnya unsur-unsur yang tidak didefinisikan, unsur-unsur yang didefinisikan, aksioma atau postulat, dan dalil. Tahap keakuratan, siswa sudah dapat memahami bahwa adanya ketepatan (presisi) dari apa-apa yang mendasari itu penting.

Penelitian pada teori triarchic Stenberg (Papalia dan Ruth, 2014:340) menyatakan bahwa anak dapat belajar dengan baik bila diajar dengan metode bervariasi, menitikberatkan pada kreativitas dan kemampuan dalam praktik, seperi halnya daya ingat dan pemikiran kritis. Lebih Lanjut Papalia dan Ruth (2014:321) menjelaskan anak dapat berpikir logis tentang hal-hal yang telah mereka ketahui sebelumnya. Dengan kata lain, siswa dapat belajar matematika apabila materi yang dipelajari sesuai dengan tingkat perkembangan mental anak dan siswa memiliki modal pengetahuan sebelumnya untuk memahami konsep matematika selanjutnya. 
EMOSI

Woolfolk (2009:204) pembelajaran dan pemroresan informasi juga dipengaruhi oleh emosi. Emosi merupakan ungkapan perasaan berupa senang, sedih, takut, malu, dan cemas.

Berdasarkan pengamatan dan pengalaman Dienes (Ruseffendi, 1991:156), anak-anak menyenangi matematika hanya pada permulaan anakanak berkenalan dengan matematika yang sederhana. Matematika yang sederhana seperti mengenal bilangan, penjumlahan dan pengurangan, perkalian, dan pembagian. Matematika yang kompleks tidak disukai, karena untuk memahami materi yang kompleks diperlukan berbagai materi matematika.

Hudojo (2005:55) menyatakan agar anak menyukai matematika, maka matematika yang disajikan harus relevan bagi siswa. Hill (2012:5) sekelumit kisah siswa ketika belajar matematika dalam kelas, para siswa yang sedang mencari luas persegi panjang, yang sebelumnya guru menanyakan cara mencari luas segitiga dengan menggambar sebuah segitiga yang sisinya berukuran $4 \mathrm{~cm}$ dan $3 \mathrm{~cm}$ sisi yang lainnya, Alex suka matematika dan merasa senang belajar memecahkan soal-soal yang baru, oleh itu Alex akan bersemangat dan berusaha untuk menentukan luas persegi panjang tersebut, selanjutnya guru menggambar dua garis lagi pada segitiga tersebut, sehingga terbentuk persegi panjang dengan sisi miring segitiga tersebut sebagai diagonalnya, Alex memandangi gambar tersebut, kemudian tersenyum paham dan dengan gembira mengangkat tangannya seraya berkata luas persegi panjang $12 \mathrm{~cm}^{2}$.

Siswa yang tidak tahu akan jawab dari soal persegi panjang tersebut dan siswa tersebut diminta untuk menyelesaikan soal tersebut kepapan tulis, sedikit banyaknya siswa tersebut akan merasa cemas. Siswa yang berada dalam keadaan cemas dalam pembelajaran, dapat meyebabkan siswa tersebut sulit untuk berkonsentrasi atau memfokuskan perhatiannya pada pengambilan informasi dari ingatan dan pembelajaran. Jadi kecemasan dapat 
menjadi penyebab kinerja yang buruk. Kecemasan juga merupakan akibat dari ketidakmampuan siswa menjawab soal matematika di depan kelas. Stuart (Hannula et all, 2005:12) menyatakan bahwa anak yang cemas dalam belajar matematika yang dapat dilihat sebagai takut menjadi malu akan menghindari pelajaran matematika. Tindakan tersebut merupakan suatu yang tidak menguntungkan bagi siswa. Jika siswa bolos untuk kelas matematika lebih dari dua pertemuan, ketidakpahamannya akan matematika akan semakin kompleks dan akan sulit untuk memperbaiki keadaan pengetahuan matematika siswa tersebut. Oleh karena itu, penting bagi seorang guru menciptakan perasaan nyaman bagi siswa di dalam kelas dan menganggap suatu kesalahan suatu hal yang wajar dan siswa tidak akan salah lagi, bila lebih giat lagi belajar matematika. Sejalan dengan yang dikemukakan Walle (2008:31) yaitu di dalam kelas, kepercayaan siswa harus dibangun bahwa kesalahan tidak menjadi soal dan menyadari kesalahan adalah kesempatan untuk berkembang.

\section{MINAT}

Terlibat atau tidaknya seseorang dalam kegiatan pembelajaran matematika berkaitan dengan minatnya terhadap matematika. Kebanyakan siswa tidak berminat dalam matematika karena matematika itu sukar. Siswa di awal SD menyukai matematika tetapi apabila sudah di tingkat SMA banyak yang tidak menyukai matematika. Ruseffendi (1991: 222) semakin tinggi sekolah anak dan makin sukar matematika yang dipelajarinya maka makin kurang minatnya belajar matematika.

Soleh (1998:39), siswa yang tidak berhasil dalam belajar matematika salah satunya dikarenakan ketidaklengakapan pengetahuan, sedangkan pelajaran matematika terus berlanjut, jadilah matematika sebagai sebuah misteri baginya. Artinya siswa yang belum menguasai materi prasyaratnya akan mengalami kesulitan dalam mempelajari materi matematika 
selanjutnya. Hal tersebut dapat mengindikasikan siswa tidak tertarik untuk mengikuti pembelajaran matematika.

Ruseffendi (1991:233) menyatakan seseorang berminat belajar matematika karena dapat melihat kegunaan matematika, merasa senang, atau menarik perhatiannya, pengajaran gurunya yang menarik misalnya menggunakan alat peraga, permainan, teka-teki, kegiatan lapangan, kegiatan laboratorium dan sebagainya atau bahkan karena kebaikan pribadi guru matematika, atau karena matematika itu sukar menjadikannya tertantang untuk menguasainya, siswa tersebut dapat melihat keindahan matematika yaitu keteraturan benda geometri, sifat-sifat bilangan yang khas, pernyataanpernyataan singkat tapi bermakna padat, matematika argumentasinya jelas, dan sebagainya.

Membangkitkan dan mempertahankan minat siswa terhadap matematika merupakan tantangan bagi guru. Mitchell (Woolfolk,2009:205) menemukan bahwa menggunakan komputer, kelompok, puzzle membangkitkan minat pada pelajaran matematika di SMP, namun itu tidak bertahan. Woolfolk (2009:205) kegiatan-kegiatan matematika yang dapat mempertahankan minat dari waktu ke waktu yaitu kegiatan yang berhubungan dengan masalah-masalah kehidupan nyata dan partisipasi aktif di berbagai kegiatan laboratorik dan proyek.

Stipek (Woolfolk, 2009:205) menyatakan minat meningkat bila siswa merasa kompeten, meskipun awalnya tidak berminat dengan suatu subjek atau kegiatan, mereka dapat mengembangkan minat bila mereka mengalami kesuksesan. Dengan kata lain, dalam pembuatan soal matematika harus dimulai dari yang mudah, dalam artian guru memperkirakan bahwa soal itu akan dapat dijawab siswa dengan mudah, cepat, dan tepat, setelah itu dilanjut dengan soal yang tingkat kesulitannya sedang, dan dilanjutkan soal yang tingkat kesulitannya tinggi.

Berdasarkan hal tersebut guru matematika memiliki tugas yang besar untuk membangkitkan dan mempertahankan minat siswa, mengingat 
pembelajaran matematika bersifat hierarki dari yang mudah menuju kompleks dan dari konkrit menuju abstrak. Disamping itu, pembelajaran matematika yang diciptakan guru dapat membuat siswa berpandangan bahwa matematika merupakan kegiatan yang mengasyikkan.

\section{KEYAKINAN DAN SKEMA DIRI}

Anak yang berkeyakinan bahwa kecerdasan itu tidak bisa dirubah, maka ia tidak akan berbuat banyak untuk mengubahnya. Jika Ia tidak cerdas dibidang matematika maka Ia tidak akan berusaha memahami materi matematika dan tidak akan berusaha menyelesaikan soal matematika yang belum terpecahkannya.

Ruseffendi (1991:157) menyatakan matematika dianggap sebagai ilmu yang sukar, rumit, dan banyak memperdayakan. Apabila siswa berkeyakinan mampu dalam pembelajaran matematika dan mampu menyelesaikan soal-soal matematika, maka siswa akan mengerahkan lebih banyak usaha, menggunakan berbagai strategi, dan bertahan lebih lama dalam menyelesaikan soal matematika tersebut. Woolfolk (2009:220) menyatakan siswa yang memiliki keyakinan kuat untuk tugas tertentu ("Saya bagus di matematika") cenderung mengatribusikan kegagalannya pada kurangnya usaha, sebaliknya siswa yang memiliki keyakinan yang rendah ("Saya payah di matematika") cenderung mengatribusikan kegagalannya pada kurangnya kemampuan ("Saya memang bodoh").

Woolfolk (2009:222) menyatakan siswa yang percaya bahwa mereka tidak mampu menangani matematika tingkat tinggi misalnya trigonometri atau kalkulus, mereka mungkin akan mewujudkan keyakinan tersebut meskipun kemampuan aktual mereka sebenarnya di atas rata-rata dan apabila mereka percaya bahwa gagal berarti bodoh, kemungkinan mereka akan proteksi diri sekaligus self-defeating. Disini guru harus dapat memberikan dukungan bagi siswa dan meyakinkan siswa. Woolfolk (2009:223) menyatakan bahwa siswa membutuhkan bukti nyata bahwa 
usaha akan mendapatkan hasil yang sepadan, bahwa menetapkan tujuan yang lebih tinggi tidak akan menghasilkan kegagalan, bahwa mereka dapat meningkat, dan bahwa kemampuan dapat dirubah. Hal tersebut dapat dilakukan dengan memberikan contoh penemu aliran listrik lampu yaitu Thomas Alpha Edyson, yang mengalami beberapa kegagalan sebelum mencapai temuannya yang begitu besar.

\section{MOTIVASI}

Penelitian banyak menunjukkan bahwa motivasi belajar berkorelasi positif dan signifikan terhadap prestasi belajar matematika siswa. Oleh karena itu, tidak suatu hal yang mengherankan apabila guru di dalam kelas selain fasilitator juga merupakan motivator bagi siswa. Terlebih lagi guru matematika untuk memotivasi siswa dalam belajar matematika, perlu usaha keras mengingat siswa banyak bersikap negatif terhadap matematika.

Motivasi siswa dalam belajar matematika berbeda-beda, ada yang rendah dan ada yang tinggi. Guru mesti memiliki pengatahuan mendalam tentang motivasi, agar dapat mengenali siswanya yang memiliki motivasi belajar atau tidak, motivasinya rendah atau tinggi.

Tim MKPBM (2001:197), hal-hal yang mengindikasikan siswa memiliki masalah motivasi belajar matematika diantaranya: (1) siswa membolos untuk menghindari pelajaran matematika, (2) siswa gagal dalam melakukan tugas-tugas matematika, (3) siswa menolak untuk mengikuti kegiatan-kegiatan matematika, baik di dalam maupun di luar kelas. Hal di atas tidak boleh dibiarkan begitu saja, tindakan yang cepat dan tepat dari guru sangat perlu untuk mengatasi hal tersebut. Tentunya cara guru untuk memotivasi siswa itu berbeda-beda, harus dilihat dari permasalahan motivasi siswa dan penyebabnya.

Tim MKPBM (2001:197), penyebab rendahnya motivasi siswa dalam belajar matematika adalah: (1) kegagalan berulang yang dialami oleh siswa dalam menjawab soal matematika, (2) pengalaman-pengalaman yang dialami oleh siswa sebelumnya yang berhubungan dengan ketidaknyamanan dalam 
belajar matematika, (3) ketidakharmonisan dalam berinteraksi antar siswa maupun siswa dengan guru, (4) kekeliruan siswa dalam memaknai dan memahami nilai-nilai yang terkandung dalam matematika. Penyebab tersebut langkah awal dan dasar guru untuk memperbaiki motivasi belajar siswa.

Apabila motivasi belajar siswa rendah dikarenakan pengalaman kegagalan yang berulang dalam menyelesaikan soal matematika, maka guru perlu merancang tugas yang menantang namun siswa dapat menyelesaikan soal tersebut. Woolfolk (2009:137) menyatakan penelitian menunjukkan bahwa tugas-tugas yang paling memotivasi dan bermanfaat secara akademik bagi siswa adalah tugas-tugas yang menantang, namun tidak membuat mereka kewalahan. Di samping itu Tim MKPBM (2001:198) menyatakan agar siswa termotivasi belajar matematika, guru seharusnya: (1) memperlihatkan bahwa matematika bermanfaat dalam kehidupan sehari-hari, (2) menggunakan teknik, metode, dan pendekatan pembelajaran matematika yang tepat sesuai dengan karakteristik topik matematika yang disajikan, (3) memanfaatkan teknik, metode, dan pendekatan yang bervariasi dalam pembelajaran matematika agar tidak monoton. Dapat dinyatakan juga bahwa guru harus menunjukkan bahwa matematika dibutuhkan untuk memenuhi kehidupan modern ini, perkembangan teknologi ada dikarenakan matematika, dan matematika merupakan ratu dan pelayan ilmu pengetahuan. 


\section{SIMPULAN}

Faktor psikologis siswa seperti kemampuan berpikir, emosi, keyakinan dan skema diri, minat, dan motivasi anak berpengaruh besar dalam menciptakan kondisi pembelajaran matematika yang positif sehingga tercapai tujuan pembelajaran matematika yang telah dirumuskan. Materi matematika yang disampaikan dalam kelas harus disesuaikan dengan tingkat perkembangan mental anak dan pengetahuan matematika siswa sebelumnya. Guru harus bisa membuat siswa tertarik untuk belajar matematika, memiliki pengalaman sukses dalam memecahkan soal matematika, dan merasa senang dalam pembelajaran matematika. 


\section{DAFTAR PUSTAKA}

Hannula et al, 2005. Gender Comparisons of Pupils Self-Confidence in Mathematics Learning. Nordic Studies in Mathematics Education, No.3-4, (Online, http://studentportalen.uu.se/.../download.action?..., diakses 28 Januari 2015).

Hill, Winfred F. 2012. Theories of Learning. Bandung: Nusa Media.

Hudojo, H. 2005. Pengembangan Kurikulum dan Pembelajaran Matematika. Malang: Universitas Negeri Malang.

Papalia, Diane E. dan Ruth D. F. 2014. Menyelami Perkembangan Manusia. Jakarta: Salemba Humanika.

Ruseffendi, E.T. 1991. Pengantar Kepada Membantu Guru Mengembangkan Kompetensinya dalam Pengajaran Matematika untuk Meningkatkan CBSA. Tarsito: Bandung.

Soleh, M. 1998. Pokok-Pokok Pengajaran Matematika Sekolah. Jakarta: Departemen Pendidikan dan Kebudayaan.

Tim MKPBM Jurusan Pendidikan Matematika. 2001. Strategi Pembelajaran Matematika Kontemporer. Bandung: JICA UPI

Walle, John A. Van. 2008. Matematika Sekolah Dasar dan Menengah Pengembangan dan Pengajaran. Jakarta: Erlangga.

Woolfolk, A. 2009. Educational Psychlogy Active Learning Edition. Yogyakarta: Pustaka Pelajar. 